\title{
Emotional Branding of China's State-Owned Enterprises on Sina Weibo
}

\author{
Ying Hua (Corresponding author) \\ Shanghai Dianji University, China \\ Email: huay@sdju.edu.cn
}

Received: 04/03/2021

Accepted: $10 / 05 / 2021$

Published: 01/07/2021

Volume: 2 Issue: 4

How to cite this paper: Hua, Y. (2021). Emotional Branding of China's State-Owned Enterprises on Sina Weibo. Journal of Critical Studies in Language and Literature, 2(4), 3045

DOI: https://doi.org/10.46809/jcsll.v2i4.76

Copyright ( 2020 by author(s) and Global Talent Academy Ltd. This work is licensed under the Creative Commons Attribution International License (CC BY 4.0).

http://creativecommons.org/licenses/by/4.0/

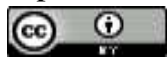

\begin{abstract}
In order to provide the interpersonal, rhetoric and semiotic insights for studying corporate emotional branding discourse on social media, this study attempts to target China's state-owned enterprises which represent the pillars of national economy with Chinese characteristics and shed light on the discourse realizations of their emotional branding strategies from the textual and interpersonal perspectives. Specifically, the present study focuses on the two kinds of textual and interpersonal representations on China-based Sina Weibo: 1) the use of stylistic features; 2) the use of attitudinal appeals. A corpus of forty-day updates of the three giant Chinese state-owned enterprises on Sina Weibo is retrieved and analyzed quantitatively and qualitatively. The results suggest the prevalence of involving stylistic features, the proliferation of affect and judgment appeals and the hybridization of appreciation and affect/judgment, which posits interdiscursivity and intertextuality in communicative functions. China's state-owned enterprises communicate to forge emotional bonding with the public other than promote their products. This pragmatic shift towards solidarity facework is indicative of a transcultural phenomenon elicited by digital globalization and the neoliberalist trend in China's national economy.
\end{abstract}

Keywords: Interpersonal, Rhetoric, Semiotic, Emotional Branding, China's State-Owned Enterprises

\section{Introduction}

China's changes since 1979, like the reform and opening-up, China's entry into WTO and digitalisation in China, have fueled China's move towards market economy mixed with the neoliberal elements that have been "released by the relaxation of authoritarian centralised control" (cited in Reghunadhan, 2018, p.24). The working definition for "neoliberalism" is "a market-driven approach to economic and social policy based on neoclassical theories of economics (aka capitalism) that maximise[s] the role of the private business sector in determining the political and economic priorities of the state" (cited in $\mathrm{Wu}, 2010$, p.619). China's neoliberal mindset is embodied in the processes of marketization, privatization, corporatization, decentralization of state enterprises and others (So, 2007). Albeit quite a few studies are skeptical about contemporary China as "neoliberal" (e.g. Ong, 2007; Huang, 2008; Nonini, 2008) owing to its state control in economic development, China's practices and transitions may be still considered "actually existing neoliberalism" "combining market advancement with state control", a specificity of "variegated forms" of neoliberalism (Wu, 2010, p.627). Market transition, as a trajectory of "neoliberalization" underlies the specific case of China (Wu, 2010, p.629). Wide-ranging restructuring and marketization of China's state-owned enterprises is a typical attempt to implement the neoliberal agenda (Weber, 2018). To enhance 
competitiveness in global markets, China's state-owned enterprises have inevitably turned to corporate branding strategies, for "the corporate brand - with its identity, image, and reputation-becomes the center of gravity for valuable and durable relationships between the firm and all interested parties" (Vernuccio, 2014, p.211). So far, social media's availability of technological affordances to engage stakeholders who contribute and co-produce the values underlying brands has made it the most promising communication environment for corporate brand building (Vernuccio, 2014). On the other hand, social media, as a tool of digital globalization, connects people and organizations across all cultures together. "Profound changes in global communication, particularly in social media, are now causing us to reexamine our notions of culture, communication, audience and identity" (Atay \& D'Silvia, 2019, p.2). The landscape of intercultural communication has been transformed in the mediated virtual environment. Mediated discourse in social media platforms makes a difference to understanding intercultural communication as illustrated in the following four aspects: To begin with, mediated communication across the globe inevitably leads to cultural fluidity and hybridity which blends virtual culture and popular culture; secondly, "visual culture and visual persuasion" are influential for the audience to construct their cultural identities; thirdly, our identities are co-constructed through human-media interactions; lastly, a kaleidoscope of ideologies in the globe are framed in mediated texts (Atay \& D'Silvia, 2019, p.3). Therefore, studying social media discourse in relation to sociocultural transformation is critical and timely. According to the Q2 Financial Report of Weibo statistics 2019, with the reported 486 million monthly active users, Sina Weibo, one of the most popular social media sites in China, has increased its number of monthly active users by approximately 310 million users since 2014 . With a year-on-year growth of $34 \%$ in the number of brand advertisers, Sina Weibo has generated an increase of 283 million in marketing revenues since 2014 (Weibo Corporation, 2019). "Weibo offers a wide range of advertising and marketing solutions to companies of all sizes" (Weibo Corporation, n.d.). Against these backgrounds, despite increasing studies on corporate social media branding, preceding studies have mainly focused on the technical and content issues (e.g. Vernuccio, 2014; Waters et al., 2009; Men \& Tsai, 2012) and very few studies have examined the discursive features associated with corporate emotional branding strategies on social media (e.g. Wu \& Li ,2018; Feng \& Wu, 2017). Drawing upon the discourse-semiotic analysis of China's state-owned enterprises' emotional branding strategies construed in the textual and interpersonal domains on China-based Sina Weibo, this study aims to shed light on the cultural influences of digital globalization and the neoliberalist trend in China on state-owned enterprises' social media branding practices.

\section{Literature Review}

\subsection{Corporate Branding on Social Media}

"Brands are systems of functional and emotional values" (Vernuccio, 2014, p.212). Conventional branding highlights the recipient role of customers (Normann \& Ramirez, 1993). Through social media, customers directly converse with corporations, the interactivity and openness resulting in "challenges and opportunities for branding" (Vernuccio, 2014, p.213). Therefore, social media, as a double-edged toolkit for corporate branding has drawn rising academic interest. There are two lines of inquiries in the research realm of corporate branding strategies on social media. The first line of inquiry is grounded in technical and content features. For example, Vernuccio (2014) codes the technical and content features of openness and interactivity of 60 firms' online communication texts by quantitative content analysis. Premised on a codebook of public relations strategies in the aspects of disclosure, information dissemination and involvement, Waters et al. (2009) content analyze how non-profit organizations exploit Facebook to enhance their popularity. In order to gauge whether culture shapes companies' relationship management strategies on Renren versus Facebook, Men \& Tsai (2012) highlight the technical strategies in terms of disclosure, information dissemination, interactivity, involvement, content of corporate posts and content of user posts. Inasmuch as linguistic nuanced and in-depth insights into the interactive meaning of corporate branding discourse on social media (Wu \& Li, 2019), the second line of inquiry has drawn upon linguistic contributions. For example, Wu \& Li (2018) explore global brands' emotional branding strategies over Sina Weibo and Twitter which are realized through the sociolinguistic forms of relational communication. Feng \& Wu (2017) identify that Chinese corporations employ involving stylistic features like netspeak, humor or hyperbole, chicken-soup-for-the-soul to satisfy the emotional needs of the publics. Drawing upon computational linguistics, Jabreel, Moreno \& Huertas (2016) conduct automated semantic content analysis of the Twitter accounts of the European destinations and the tweets of their visitors for comparisons of emotional values. Via interactional sociolinguistic approaches, Li \& Wu (2016) investigate how the three corporate relational acts of information dissemination, achievement sharing and interacting with publics are materialized by linguistic and symbolic means. By adopting conversation analysis of the company-consumer interactional data and drawing upon the notions of "footing", "category entitlement" and "stake" from interactional sociolinguistics, Lillqvist \& LouhialaSalminen (2013) present the corporate myriad impression management strategies to engage critical consumers on Facebook (cited in Lillqvist \& Louhiala-Salminen, 2013, p.11).

The previous literature has shifted attention towards the analysis of corporate branding strategies by drawing upon the theoretical insights from interactional sociolinguistics, pragmatics and computational linguistics in order to tap more potential for corporate engagement with stakeholders on social media. Nonetheless, such research is still few and far between. What's more, a majority of studies focus on textual representations associated with company-customer interaction. Interpersonal and rhetorical meaning warrants consideration. Sentiments as automated computational analysis can detect, it poses challenges to 
draw accurate conclusions from the categorizations made by a machine (Zappavigna, 2012). Anyway, visual resources other than linguistic resources deserve close scrutiny as well towards multimodal meaning making.

\subsection{Emotional Branding}

In lieu of sheer benefit-driven branding, emotional branding, a concept in marketing communication, is defined as "engaging the consumer on the level of senses and emotions; forging a deep, lasting, intimate emotional connection to the brand that transcends material satisfaction; ...creating a holistic experience that delivers an emotional fulfillment so that the customer develops a special bond with and unique trust in the brand" (Morrison \& Crane, 2007, p.410). In tapping the construct of emotional branding, the concept of emotion needs to be highlighted. O'Shaughnessy \& O'Shaughnessy (2003) involve evaluative appraisal as the response to the stimulus which generates emotions. Ajzen (2005) theorizes mediated attitude(emotion) as a link to motivating customer behavior. "To arouse an emotion, the object must be appraised as affecting me in some way, affecting me personally as an individual with my particular experience and my particular aims" (Arnold, 1960, p. 171). Appraisal, an interpersonal domain where language is used to express attitude, concerns "how writers/speakers align or disalign themselves with actual or potential respondents" and how "texts of communities of shared feelings and values" are constructed, thus enacting bonding, "around which shared reverberations we align into communing sympathies of kinship, friendship, collegiality and other of the many kinds of affinity and affiliation" (Martin \& White, 2005, pp.1,211). Besides, emotional branding is conceptualized as a strategy to position brand in the hearts of customers other than creating branding awareness (Morrison \& Crane, 2007), to whose fulfillment authenticity and legitimacy is central (Erickson,1995; Harter, 2002). "Rhetoric plays a central role in informing our understanding of how corporate entities legitimize themselves through discourse by displaying their corporate soul to both internal and external publics" (Jørgensen \& Isaksson ,2010, p. 516). Aristotle defines "ethos", "pathos", "logos" as the three modes of persuasion used to convince audience (Hyland, 2005, p.64). "Ethos concern the character of the speaker and his or her credibility"; "pathos concern affective appeals and focus on the characteristics of the audience"; logos entail rational appeals of the argument (Hyland, 2005, pp.64-65). Since language is taken as the primary means to exchange persuasive messages, "the semantics of persuasion get expressed as interpersonal meanings", on which "selections of attitude" perform a rhetorical effect to form bonds between writers and readers (Dvorak, 2015, pp.92, 96). Following this line of thinking, attitude is heralded as a tenet in emotional branding.

Gobe (2009) delineates the three developmental stages of emotional branding in US, i.e. "the Pragmatist Age", "the Evangelist Age", "the Sensualist Age" (p. 128). The pragmatist age highlights "products' or service's reliability and pragmatic functions" performed by "omnipresent advertising"; the evangelist age represents "philosophies of social justice, equality and sensitivity to the environment"; the sensualist age seeks "hedonism, glamour, fame and individual expressions" (Wu \& Feng, 2015, p.227).Wu \& Chung (2006) systematically investigate the use of involvement strategies in advertising from the two perspectives of advertising themes and linguistic features, identifying a sharp increase in symbolic themes and linguistic features of involvement for appealing to the self-conscious desires among the Hong Kong people. Employing the theory of generic intertextuality between informative style and involving style, Feng \& Wu (2007) reveal a transformation towards the hybridity of informative and involving styles in China's advertising discourses, attributed to the changing ideological values of the mainland Chinese in the past two decades. Feng \& Wu (2009) find an increase of hedonistic value appeals and interactive linguistic features characterizing the advertising discourses of Nanfang Daily in 2002 compared to the predominant utilitarian values and formal lexico-grammatical features in the 1980 counterparts. Feng \& Wu (2017) and Wu \& Li (2018) contribute to microanalysis of emotional branding strategies in social media discourse, drawing upon the theoretical traditions of thematic appeals cum stylistic features and thematic appeals cum interactional strategies respectively. More discursive domains of emotional branding on social media need to be tapped in addition to textual representations.

\section{Methodology}

\subsection{Research Objective and Questions}

Against the aforementioned practical and theoretical concerns, this study attempts to offer micro-analytical insights into the discourse realizations of Chinese state-owned enterprises' emotional branding strategies on China-based Sina Weibo from textual and interpersonal domains and their further reflection of the sociocultural changes in contemporary China, as specified by the following three research questions:

RQ1: What are the discourse realizations of Chinese state-owned enterprises' emotional branding strategies on Sina Weibo in terms of stylistic features?

RQ2: What are the discourse realizations of Chinese state-owned enterprises' emotional branding strategies on Sina Weibo in terms of attitudinal appeals?

RQ3: How do the identified discourse features reflect the sociocultural changes in contemporary China?

3.2 Framework of Analysis

In the present study, emotional branding is defined as an essential strategy to enact loyalty-sustaining and emotionallypositioning brand-customer connections. Specifically, this present study concerns the discourse realizations of emotional branding strategies adopted by Chinese state-owned enterprises in both textual and interpersonal domains which delve into the textual and interpersonal meta-functions of language (Halliday, 2014). Specifically, the present study focuses on the two major kinds of textual and interpersonal representations: 1) the use of stylistic features; 2) the use of attitudinal appeals. 
The framework for analyzing stylistic features is based upon Feng \& Wu's (2007) typological dimensions of lexicon, syntax and rhetoric of informative/involving style. The three stylistic idiosyncrasies of Internet neologism, adjacency pair and pun in the respective aspects of lexicon, syntax and rhetoric are identified. Given attitudinal appeals, Martin \& White's (2005) attitudinal system of affect, judgment and appreciation in their seminal appraisal framework is drawn upon (See Figure 1). The framework for analyzing attitudinal appeals is further elaborated by Feng's $(2012,2016,2017)$ framework for semiotic construction of evaluative attributes, which distinguishes linguistic and visual resources in analyzing attitudinal meaning (See Figure 2). Attitudinal resources can be articulated explicitly through evaluative lexis such as "like", "happy", "thankful" or salient metaphor such as "Internet use is like dining or drinking". Implicit articulation can be achieved through any eliciting condition elucidating "the behavior that causes the attitude" or the resultant speech act motivated by the attitude (Feng, 2016, p.91). Evaluative attributes can also be constructed by the use of multimodal resources other than by use of linguistic resources. For analysis of attitudinal appeals in embedded multimodal resources, we distinguish actional process, analytical process (Kress \& van Leeuwen, 2006) and visual narrative design (Feng 2016). Actional process refers to the activities corporates post on social media. Analytical process looks for details such as facial expressions, clothing, accessories, etc. Visual narrative design assigns attributes to different characters in storytelling and manipulates their development (Feng, 2016).

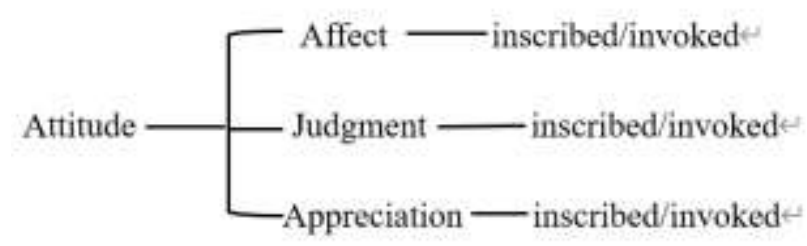

Figure 1. The attitudinal system (Martin \& White, 2005)

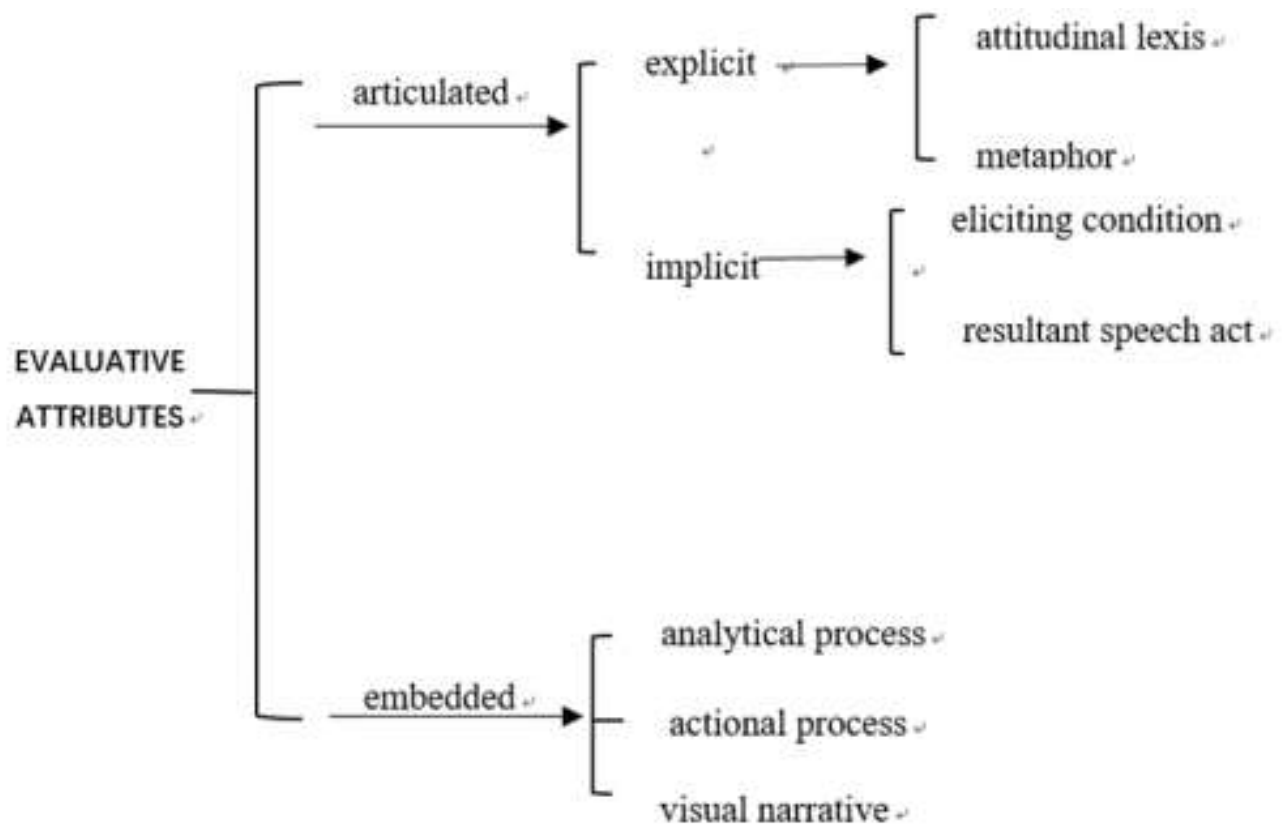

Figure 2. The framework of semiotic construction of evaluative attributes (Feng, 2012, 2016, 2017)

\subsection{Data}

Building on the ranking list of "2019 BrandZ ${ }^{\mathrm{TM}}$ Most Valuable Chinese Brands Top 100" (Guo, n.d.), sequentially the researcher selects the top 3 state-owned enterprises in different types of pillar industries. Finally, Industrial and Commercial Bank of China abbreviated as ICBC in the industry of financial service, China Mobile in the industry of telecommunications and China Petroleum \& Chemical Corporation abbreviated as Sinopec in the industry of energy are sampled on the subject list. Their official posts on Sina Weibo for a period of 40 days (Oct. 14 -Nov. 22, 2019) are randomly selected for quantitative and qualitative analysis. One thousand and twenty-nine posts in total have been extracted. See the data profile as follows (Table 1). 
Table 1 Data profile

\begin{tabular}{|c|c|c|}
\hline No. & Company & Posts \\
\hline 1 & $\begin{array}{c}\text { Industrial and } \\
\text { Commercial Bank of } \\
\text { China (ICBC) }\end{array}$ & 39 \\
\hline 2 & China Mobile & 751 \\
\hline 3 & $\begin{array}{c}\text { China Petroleum \& } \\
\text { Chemical Corporation } \\
\text { (Sinopec) }\end{array}$ & 239 \\
\hline \multicolumn{2}{|c|}{ Total } & $\mathbf{1 , 0 2 9}$ \\
\hline
\end{tabular}

\subsection{Data Analysis}

The randomly selected posts of the three China's state-owned enterprises on Sina Weibo are analyzed microanalytically and multimodally in terms of stylistic features and attitudinal appeals. Since language is "not only a system of symbols for expressing thoughts and representing human activities and goals, but also a cultural practice, that is, a form of action that both presupposes and at the same time brings about unique ways of being in the world" (Keating \& Duranti, 2011, p.2), drawing upon the identified corporate discursive features and strategies on China-based social media as evidence, we can discern the sociocultural changes reshaped by the global contexts of digital culture and economic globalization.

3.4.1 Stylistic Analysis

Stylistic features are analyzed from the perspectives of lexicon, syntax and rhetoric respectively exemplified by Internet neologism, adjacency pair and pun.

3.4.1.1 Internet neologism

The affordances of Internet bring about several distinctive features of a language variety (Crystal, 2001). Netspeak rises as a type of "electronic, global, and interactive" language displaying features unique to Internet (Crystal, 2001, p.20). "The most noticeable characteristic of netspeak is the neologisms" whose formations include attaching new meaning to the old word (Liu \& Liu, 2014, p.23). The shared and unique terminologies or neologisms serve to transmit the embedded meaning online and organize people into groups for better socialization. Neologisms are prevalent in the corporate posts of three Chinese state-owned enterprises. For example,

\section{Extract 1}

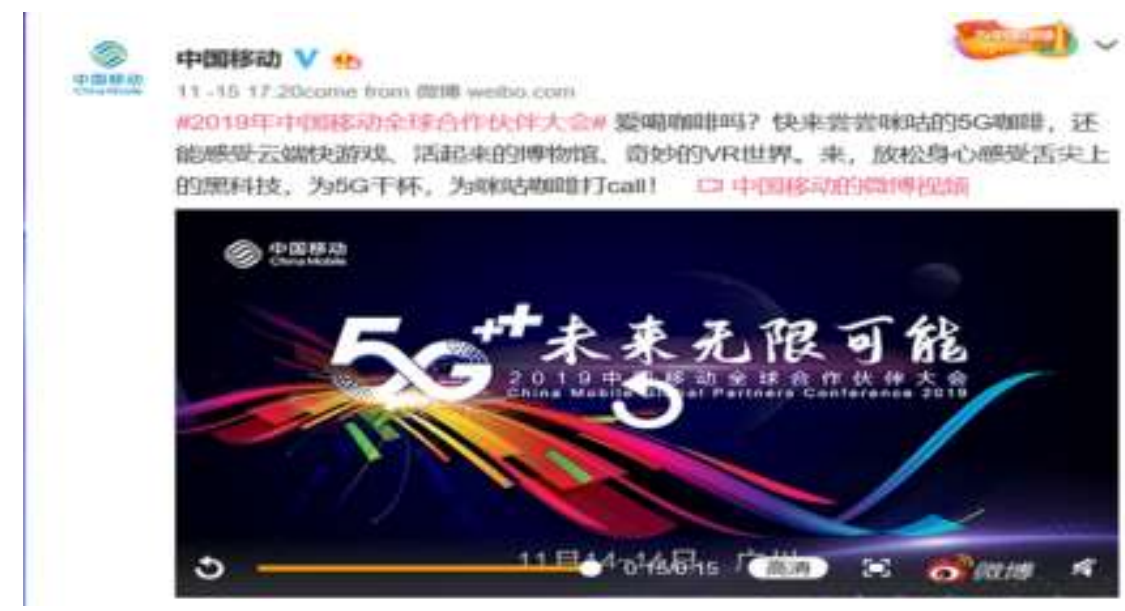

\section{Extract 1: Translation:}

\#2019 China mobile global partner conference\# love coffee? Come and taste the 5G coffee of Migu, and experience the cloud games, the living museum and the wonderful VR world. Come on, relax and feel the black technology on the tip of your tongue, toast $5 \mathrm{G}$ and cheer for Migu coffee!

China Mobile employs the Internet neologism "Da call" whose English translation is "cheer for" or "support". "Da call”, ranked No.1 among the top 10 Chinese Internet terms of 2017 (Cao, 2018), originates from a practice of fans waving glow sticks and cheering to the rhythm in support for the idol singer on the stage in Japanese idol culture. It has extended its meaning from showing likings towards actors to appreciating everything nice. It has gone viral on Internet due to the two reasons: Firstly, its original practice in Japanese idol culture can quickly arouse the sense of participation from audience; secondly, its semantic evolution fits the harmonious appeals in Chinese culture. By use of "Da call", China Mobile acts like a popular singer on the stage, sparing no efforts to motivate the fans to " $D a$ call" for him. The Netspeak use not only 
personifies China Mobile, but evokes the publics' identification and manages the bond between China Mobile and publics as well.

3.4.1.2 Adjacency Pair

Schegloff \& Sacks (1973) defines an adjacency pair as a pair of turns at talk. The first turn is called "first pair parts" (FPP), which provokes the second turn called "second pair parts" (SPP) (p.74). FPP establishes a setting for interaction while SPP responds to FPP in a preferred or dis-preferred manner labelled as "different interactional import" (Liddicoat, 2011, p.144). An adjacency pair is used to establish a working rapport between the two interlocutors. Take Extract 2 for instance.

\section{Extract 2}

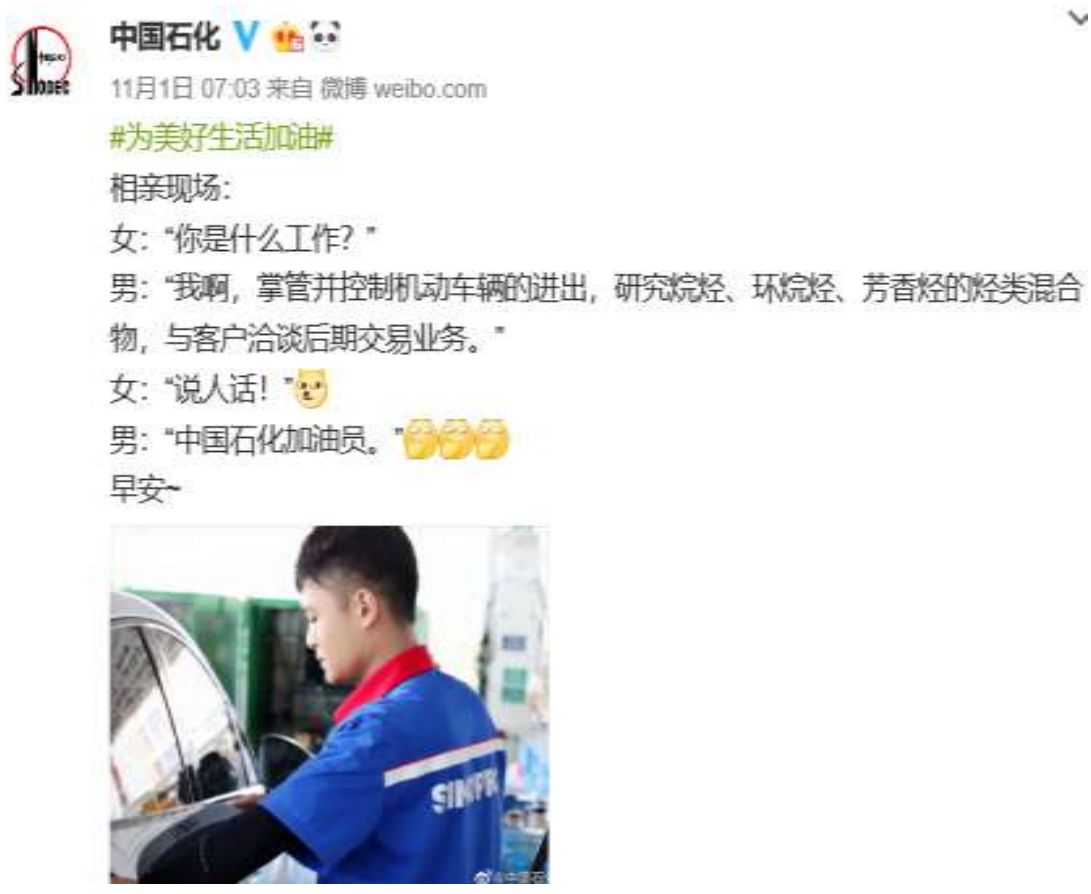

\section{Extract 2: Translation:}

\#Cheer for a better life\#

The scene of a blind date

Female: "What is your job?"

Male: "I am in charge of controlling the entry and exit of motor vehicles, researching hydrocarbon mixtures of alkanes, cycloalkanes and aromatic hydrocarbons, and negotiating post-transaction business with customers."

Female: "Talk like a real person!"

Male: "A Sinopec gas fueler."

Good morning

The conversation is set at the scene of a blind date. There are two adjacency pairs (Schegloff \& Sacks, 1973) in the conversation. In traditional Chinese marriage values, social statuses of spouses are highlighted. In order to improve selfimage and respect the other side, in the first adjacency pair of question-answer, the man employed positive face strategies by responding in technical and embellished terms which flouted the maxims of manner (Grice, 1975). Aware of the violation of right to know as a negative face threat, the woman formulated a request to demand the man as a bald-on-record face threatening act. In the second adjacency pair of request-acceptance, the man complied to her desire and adopted emoticons to mitigate the tension. On the surface, the exploitation of facework strategies in the conversational interaction is to manage rapport between the two parties in the blind date. It per se aims to appeal to more resonance from audience by personifying and highlighting the role of Sinopec.

3.4.1.3 Pun

The figurative speeches such as metaphor, pun, rhetorical questions are considered the pivotal "marketing linguistic devices that influence brand attitudes and choice" to make corporate branding more persuasive (Pogacar, Lowrey \& Shrum, 2017, p.263). 


\section{Extract 3}
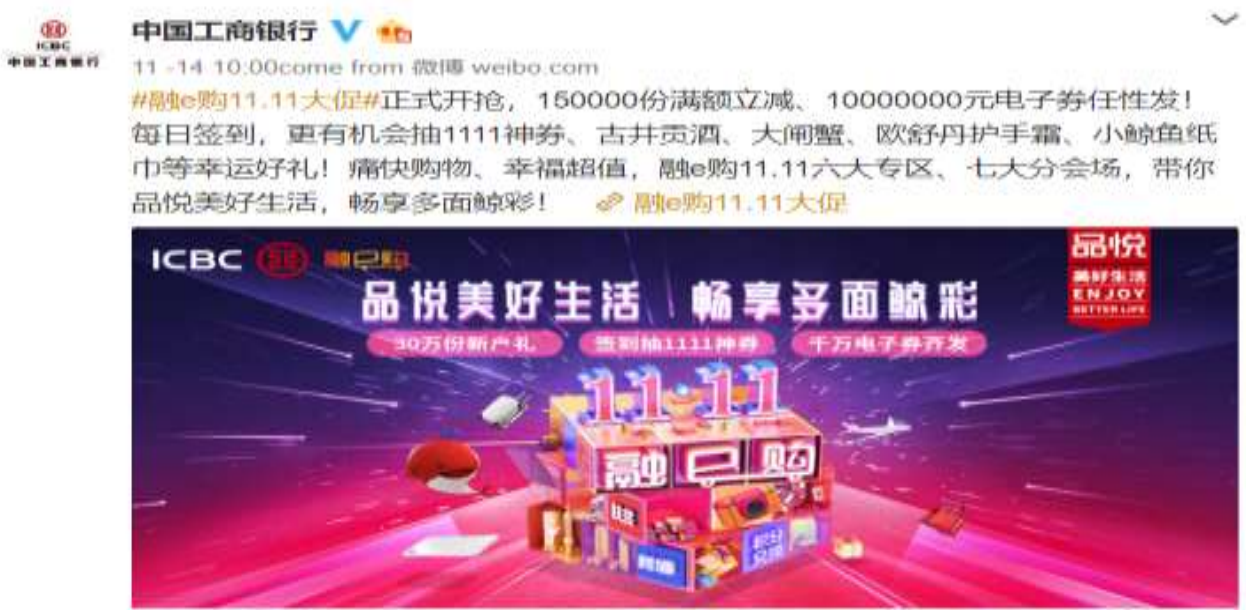

融e购11.11大促

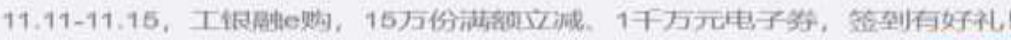

\section{Extract 3: Translation:}

\# Finance E-purchase Nov.11 Big Promotion \# open to purchase officially, 150, 000 reductions with quota fulfilled, 10,000,000 RMB electronic coupons presented! Daily check in and have the opportunity to draw 1,111 RMB lottery tickets, Gujinggong wine, hairy crab, L'OCCITANE hand cream, small whale tissues and other lucky gifts! Happy shopping with overflowing happiness! The Nov.11 six special areas and seven sub-venues of finance e-purchase will bring you to enjoy good life and multi-faceted wonders!

A pun is "a humorous play on words", providing "the pleasure of solving a mental puzzle" (Pogacar, Lowrey \& Shrum, 2017, p.264). In Extract 3, ICBC deliberately appropriates the Chinese character “鲸”(whale) as a pun which generates dual meanings. On one hand, “鲸” (whale) represents the symbol of ICBC. On the other hand, in Chinese, “鲸” (whale) and “精” (wonder) are homophones. The pun therefore achieves a humorous and impressive effect, implying that ICBC's activities on Nov.11 will be brilliant.

3.4.2 Attitudinal Analysis

To make a full-fledged analysis of attitudinal appeals articulated or embedded in social media discourse, both linguistic and visual resources are taken account of in terms of three attitudinal appeals, i.e. affect, judgment and appreciation (Martin \& White, 2005). Content analysis is employed to identify the salient frequency distribution of attitudinal appeals. Drawing upon the quantitative results, qualitative analysis is exploited to display an in-depth picture of how the attitudinal appeals of Chinese state-owned enterprises are realized discourse-analytically through linguistic and visual means.

3.4.2.1 Quantitative Analysis

Following Martin \& White's (2005) attitudinal system and Feng's $(2012,2016,2017)$ framework of semiotic construction of evaluative attributes, the coding scheme detailing specific attitudinal appeals found in the sample, their definitions and their illustrations is demonstrated in Table 2. Due to the prevalent hybridization of attitudinal appeals in the posts, the coding spells out a maximum of 3 categories of attitudinal appeals for each post.

Table 2. Coding scheme for attitudinal appeals in Chinese state-owned enterprises' posts on Sina Weibo

\begin{tabular}{|c|c|c|}
\hline Attitudinal appeals & Definitions & Illustrations \\
\hline affect & $\begin{array}{l}\text { Posts that express an } \\
\text { emotional state, a physical } \\
\text { expression of that state or an } \\
\text { event that causes the emotion }\end{array}$ & $\begin{array}{l}\text { “感谢民警们的及时救助, 还有 } \\
\text { 石化蓝精灵们, 你们都是好样 } \\
\text { 的, 点赞! ”(Sinopec, October } \\
31)\end{array}$ \\
\hline judgment & $\begin{array}{l}\text { Posts that judge one's } \\
\text { character or behavior based } \\
\text { on social standards }\end{array}$ & \\
\hline judgment (inscribed) & $\begin{array}{l}\text { Posts that articulate moral } \\
\text { values in an explicit way } \\
\text { through attitudinal lexis or }\end{array}$ & $\begin{array}{l}\text { “工商银行将延续服务首届进博 } \\
\text { 会的精神风貌和专业水平, 借 }\end{array}$ \\
\hline
\end{tabular}




\begin{tabular}{|c|c|c|}
\hline & through metaphors & $\begin{array}{l}\text { 助广泛的全球布局、雄厚的客 } \\
\text { 户基础和丰富的产品体系, 以 } \\
\text { 更广泛全球参与度, 更智慧的 } \\
\text { 金融产品、更高的服务标准, } \\
\text { 在招商招展、虹桥国际经贸论 } \\
\text { 坛、配套活动、金融服务等各 } \\
\text { 方面提供全面服务, 为进博会 } \\
\text { 参会客商架起互联互通的桥 } \\
\text { 梁。” (ICBC, Nov.5) }\end{array}$ \\
\hline judgment (invoked) & $\begin{array}{l}\text { Posts that represent moral } \\
\text { values in an indirect way by } \\
\text { recounting the eliciting } \\
\text { conditions or the resultant } \\
\text { actions or by exhibiting } \\
\text { embedded attributes in } \\
\text { character actions }\end{array}$ & $\begin{array}{l}\text { “时至冬日, 天气转寒。移动志 } \\
\text { 愿者们来到淮安市三河镇联堡 } \\
\text { 村, 帮助这里的贫困户忙起了 } \\
\text { 农活, 并为他们送上慰问金, } \\
\text { 给他们带去冬日的一份温暖, } \\
\text { 老乡开心地笑了。” }\end{array}$ \\
\hline appreciation & $\begin{array}{l}\text { Posts that express evaluations } \\
\text { about things }\end{array}$ & $\begin{array}{l}\text { “哇! 5G 时代已来, 曾经畅想过 } \\
\text { 的智慧生活将一一实现 ! 科技 } \\
\text { 宝藏浸在眼前, 身临其境感受 } \\
\text { 超现实的科技碰撞, 酷感与趣 } \\
\text { 味十足, 玩转前沿黑科技! 厉 } \\
\text { 害了我们的 } 5 \mathrm{G!”} \mathrm{(China} \mathrm{Mobile,} \\
\text { Nov.15) }\end{array}$ \\
\hline
\end{tabular}

Table 3 summarizes the frequency distributions and the corresponding percentages of attitudinal appeals in Chinese stateowned enterprises' posts on Sina Weibo. Table 2 reveals that there are much more affect appeals $(\mathrm{N}=669,40.06 \%)$ or judgment appeals $(\mathrm{N}=734,43.95 \%)$ than appreciation appeals $(\mathrm{N}=267,15.99 \%)$. And an overwhelming majority of judgment appeals $(\mathrm{N}=677,40.54 \%)$ are presented implicitly.

Table 3. Attitudinal appeals in Chinese state-owned enterprises' posts on Sina Weibo

\begin{tabular}{|c|c|c|}
\hline Attitudinal appeals & N. & Percentage \\
\hline affect & $\mathbf{6 6 9}$ & $\mathbf{4 0 . 0 6 \%}$ \\
\hline judgment & $\mathbf{7 3 4}$ & $\mathbf{4 3 . 9 5 \%}$ \\
\hline judgment (inscribed) & 57 & $3.41 \%$ \\
\hline judgment (invoked) & 677 & $40.54 \%$ \\
\hline appreciation & $\mathbf{2 6 7}$ & $\mathbf{1 5 . 9 9 \%}$ \\
\hline Total & 1670 & $100 \%$ \\
\hline
\end{tabular}

3.4.2.2 Qualitative Analysis

3.4.2.2.1 Affect

In Martin \& White's (2005) attitudinal system, affect is categorized into four semantic categories of emotions: "dis/inclination", "un/happiness", "in/security", "dis/satisfaction” (p.71). 


\section{Extract 4}

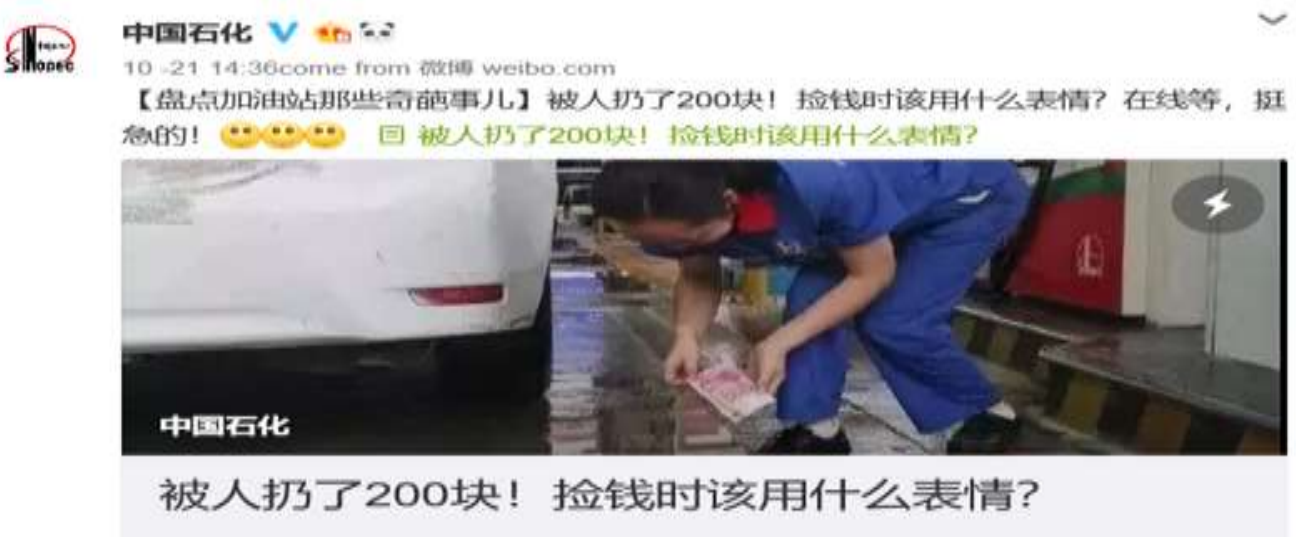

No.16

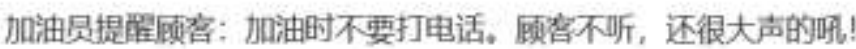

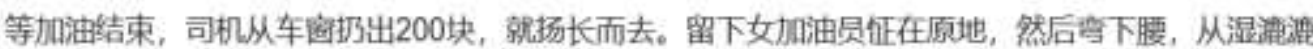
的地上捡起钱，小心兽拭干净。

路人表示: 大兄弟，你这副有钱的样子，多扔点颔 干胉让在场的人见者有份!

(Sinopec, Oct.21)

\section{Extract 4: Translation:}

200 bucks thrown at the gas station! What feelings should you express when picking up money? Wait online anxiously!

$\underline{\text { link }}$

The gas fueler reminds customers, "Do not call while refueling". The customer shouted loudly rather than followed. When the refueling was over, the driver threw 200 yuan from the car window and left. The female gas fueler remained where she was and then bent down to pick up the money from the wet ground and carefully wiped it clean. Passers-by expressed, "Big brother, you seem rich. Please throw more to let all the people present have a share!"

In Extract 4, Sinopec humorously converses with the publics by asking the publics a question with a human voice "what feelings should you express when picking up money" and explicitly conveying its strong inclination to know the responses. In the link, at first, Sinopec elicits dissatisfaction by recounting the script formulations (Edwards, 1994) that the customer shouted loudly rather than followed the gas fueler's well-intentioned reminder and threw 200 yuan rudely from the car window to deliberately cause many troubles for the gas fueler to pick up the money. Afterwards, Sinopec supplements the public comments as resultant speech acts to implicitly reinforce such negative emotion. In reality, Sinopec is rather dissatisfied with this rude behavior of disrespecting their gas fueler's work. Nonetheless, it renders such complaint invokingly and convincingly by recounting the facts and endorsing external voices.

3.4.2.2.2 Judgment

As Martin \& White's (2005) attitudinal system delimits, judgment can be coded into one's social esteem in terms of capacity, tenacity, normality and social sanction in terms of morality. For example, 


\section{Extract 5}

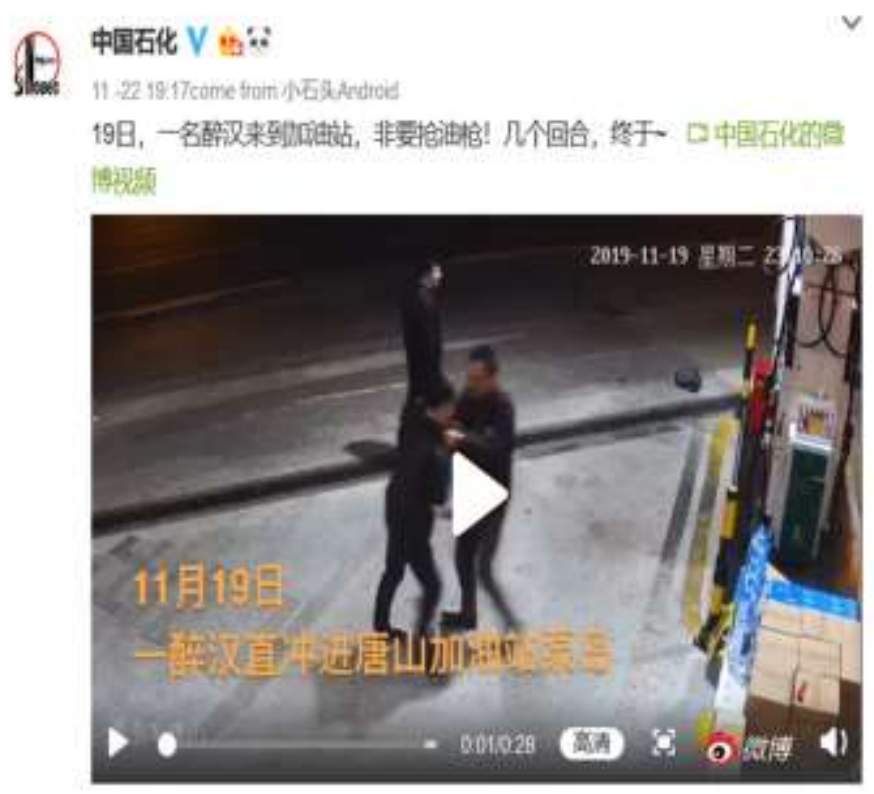

(Sinopec, Nov.22)

\section{Extract 5: Translation:}

On Nov.19, a drunkard came to the gas station and kept grabbing gas gun! Through several rounds, finally

\section{Extract 5: Segmentation and transcription}

\begin{tabular}{|c|c|l|l|}
\hline Segments & Visual image & $\begin{array}{l}\text { Image } \\
\text { description }\end{array}$ & $\begin{array}{l}\text { Verbal } \\
\text { transcription }\end{array}$ \\
\hline setting & $\begin{array}{l}\text { A drunkard was } \\
\text { rushing into the } \\
\text { pump island of } \\
\text { Tangshan Gas } \\
\text { Station. }\end{array}$ & $\begin{array}{l}\text { On Nov.19, a } \\
\text { drunkard rushed } \\
\text { into the pump } \\
\text { island of } \\
\text { Tangshan Gas } \\
\text { Station. }\end{array}$ \\
\hline development & & $\begin{array}{l}\text { Dissuaded by } \\
\text { his companion, } \\
\text { the drunkard } \\
\text { was smashing } \\
\text { the pump island } \\
\text { into a mess. }\end{array}$ & $\begin{array}{l}\text { The drunkard } \\
\text { smashed the } \\
\text { pump island so as } \\
\text { to cause a mess } \\
\text { on the ground, } \\
\text { who was } \\
\text { dissuaded } \\
\text { repeatedly by his } \\
\text { companion. }\end{array}$ \\
\hline problem & & $\begin{array}{l}\text { The gas fueler } \\
\text { moved forward } \\
\text { immediately. } \\
\text { Seeing the } \\
\text { drunkard } \\
\text { grabbing the gas } \\
\text { gun, Xing } \\
\text { Ningfang, a } \\
\text { fueler held on to } \\
\text { the gas gun. } \\
\text { Tearing with the } \\
\text { drunkard, Xing }\end{array}$ \\
\hline
\end{tabular}




\begin{tabular}{|l|l|l|l|}
\hline reaction & & $\begin{array}{l}\text { Ningfang was } \\
\text { beaten. }\end{array}$ & \\
\hline solution & & $\begin{array}{l}\text { Several people } \\
\text { were trying to } \\
\text { pull the } \\
\text { drunkard apart. }\end{array}$ & $\begin{array}{l}\text { Several people } \\
\text { joined efforts } \\
\text { together to pull } \\
\text { the drunkard } \\
\text { apart. }\end{array}$ \\
\hline
\end{tabular}

In Extract 5, based on the transcripts, the video narrates a true story multimodally with the sequential phases of setting, development, problem and solution. Contextualized in the scenario of a drunkard rushing into the pump island of Tangshan Gas Station, the narrative arouses the intense interest from audience. As the situation deteriorates rapidly, it becomes more breath-taking. When the audience see the drunkard cause the immoral conflicts by beating the righteous gas fueler who is courageously guarding the oil gun regardless of physical injury, dissatisfaction and empathy arises spontaneously. When the extreme conflict is settled by positive values defeating negative ones, positive emotion is engaged. The embedded multimodal narrative discourse is typical of Labov's (1972) structural model of narratives and Manichean moral structure (Smith, 1995). Through the multimodal visual narrative, the character traits of courage and faithfulness are promoted to invoke corporate heroic tenacity. In the meantime, with emotion prosody in which "discursive voice manipulates the viewer in similar ways" to character emotions (Feng \& Wignell, 2011, p.584), the meaning is constructed by the viewer themselves, making people more easily persuaded (Jeong, 2008).

\section{Extract 6}

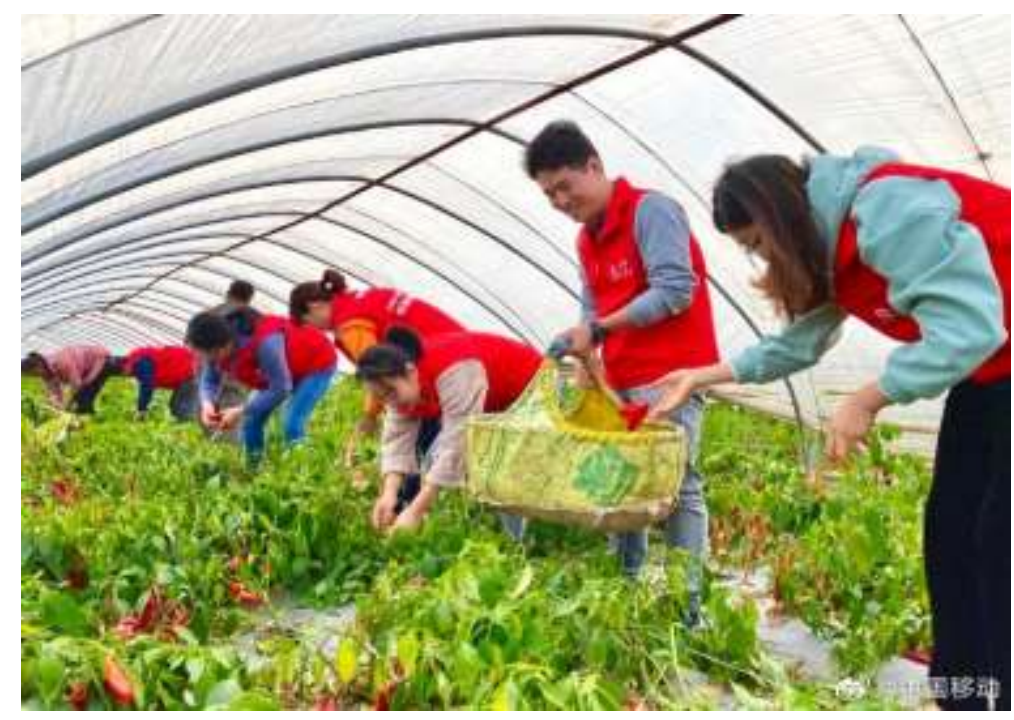

(China Mobile, Nov.20)

In Extract 6, in terms of analytical process, the red vests with the label of China Mobile identify the people in the image as the staff volunteers from China Mobile. Regarding actional process, with smiles, they seem very happy helping the landlord to harvest the ripe peppers in the field. All the aforementioned multimodal resources impress the publics with the attributes of propriety and charitableness of China Mobile. 


\subsection{Appreciation}

Appreciation is embodied in expressing evaluations about things like corporate produce (Martin \& White, 2005).

\section{Extract 7}

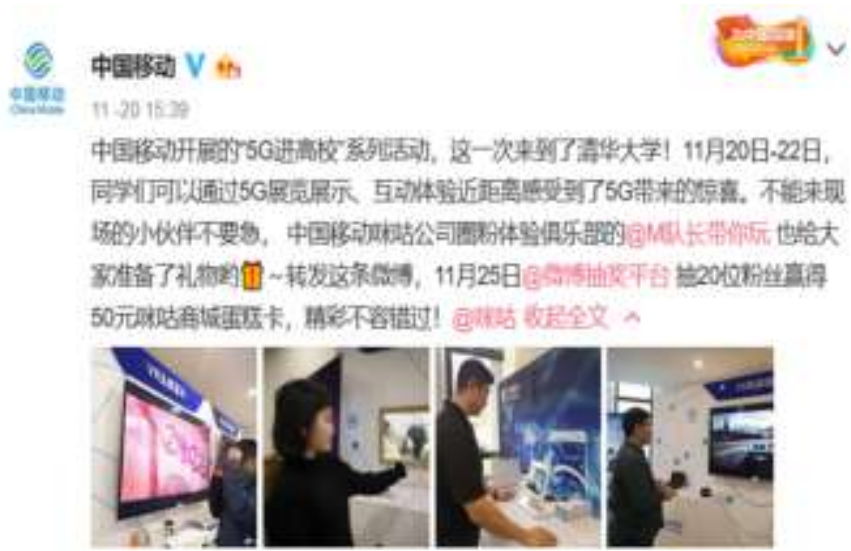

\section{Extract 7: Translation:}

A series of activities "5G into universities" launched by China Mobile are held in Tsinghua university this time! From November 20 to 22, students can feel the surprise brought by 5G through 5G exhibition and interactive experience. Who can't attend please don't worry. @ Captain M Playing with You of the circle fan experience club of Migu company of China Mobile has prepared gifts for you as well Iึ r . Repost this post. @Weibo Lucky Draw Platform twenty fans will have the opportunities to win Migu Mall cake card with a value of 50 yuan on Nov.25. Don't miss the wonders!

China Mobile explicitly highlights the surprise brought by its $5 \mathrm{G}$ service, which is a salient indicator of appreciation. What's more, appreciation is hybridized with affect, for China Mobile shows its strong inclination to invite the fans to repost even with material stimuli. In Chinese culture, associated with power distance, material benefits are used to ingratiate others as a positive politeness strategy. The communicative functions of advertising and entertaining are inter-textualized to better persuade the consumers.

\section{Extract 8}

\section{Extract 8: Translation:}

The Military Games are about to open in Wuhan. Check out this report from People's Daily to find out how ICBC is serving the Military Games. \#ICBC is caring\# Close service of foreign currency exchange throughout the whole day.

Extract 8 appreciates the all-day-long considerate service of foreign currency exchange supplied by ICBC. Moreover, the voice of People's Daily, a mainstream newspaper in China is attributed to elucidate the sensitive, caring and kind character of ICBC who devotes to serving military soldiers and social activities full-heartedly. The appeals of appreciation and judgment are hybridized.

\section{Findings}

Subsequent to corpus-based analysis, Biber (1988) distinguishes the two major stylistic categories, i.e. informative style and involving style. Biber (1988) characterizes informative style by the frequent use of long sentence, compound sentence, complex noun phrase or written language whilst characterizing involving style by the frequent use of short sentence, first or 
second pronoun, spoken language or colloquialism. Feng \& Wu (2007) defines informative style as an inclusion of informative lexicon, declarative syntax excluding any rhetorical device whilst categorizing the specificities of involving style into involving lexicon or first or second pronoun at lexical level, question-answer pair, question or exclamation at syntactical level, pun, personification or parallelism at rhetorical level. Informed by the lexical, syntactical and rhetorical analysis of neologism, adjacency pair and pun, we have identified a salient conversational, interactional, personal, involving discursive style employed by the three China's state-owned enterprises to actively engage the audience in interaction. In terms of attitudinal appeals, judgment or affect appeals far outweigh appreciation appeals. Most judgment appeals are expressed in an invoking manner. The use of multimodal resources gives a vivid picture of corporate personality traits, therefore developing a brand persona that connects "what a company says and what it does" so as to enact "a long-lasting emotional bond with the audience" (Herskovitz \& Crystal, 2010, p.21). The implicit articulation of negative affect in the case showcases corporate calmness, restraint and politeness strategies. Affect and judgment appeals are "centered on participants" (Hyland, 1998, p. 233). Appreciation appeals no longer exist exclusively but in mixture with affect or judgment appeals, which contributes to the communicative interdiscursivity and intertextuality of Chinese corporate branding posts on Sina Weibo. Inasmuch as the acknowledged correspondence between attitudinal appeals and Aristotle's rhetoric ethos (credibility), pathos(emotion) and logos(rational argument) (Macken-Horarik et al. ,2017), it posits that albeit the existing discursive manifestations of highcontext orientations and power distance, Chinese state-owned enterprises shift to vigorously personifying themselves, building solidarity with publics and promoting credibility among publics rather than merely advertise or broadcast downward ( $\mathrm{Li} \& \mathrm{Wu}, 2018$ ). To sum up, the microanalytical findings mark a shifting trend of Chinese state-owned enterprises' enthusiastic devotion to promoting solidarity and interactivity with the public in order to resonate with them instead of hardsell advertising.

\section{Discussion and conclusion}

Drawing upon Gobe's (2009) delineation of three phases of emotional branding, i.e. "the Pragmatist Age", "the Evangelist Age", "the Sensualist Age" (p. 128),the findings concluded from the microanalysis corroborate that Chinese stateowned enterprises' branding on Sina Weibo has transcended pragmatist branding to the prevalence of evangelist branding and sensualist branding in order to develop customers' sustainable emotional bonding towards the brands.

The Confucian values deeply rooted in traditional Chinese culture delimit the concept of $l i$ which is identical with the word "politeness" as "self-denigration" and "addressee-elevation" (Pan \& Ka'da'r, 2011, p.1528). As this linguistic honorific system is robustly embedded, the "hierarchical politeness system" defined by Scollon \& Scollon (1995) is still applied in modern Chinese social interactions regarding "power differences" and "social distance" (Pan \& Ka'da'r, 2011, p.1536). This statement is strongly argued by the two Chinese scholars, i.e. Gu (1990) who contends with the cultural specificities of politeness in modern China incorporating the maxims of "respectfulness", "modesty", "attitudinal warmth" and "refinement" (p.239) and later Mao (1994) who clarifies Chinese face as "a Chinese desire to secure public acknowledgement of one's prestige or reputation" (p. 460). They have both challenged Brown \& Levinson's (1987) dichotomy of positive and negative face as universal in all cultures, postulating that Brown and Levinson's view on face is individual-based and Euro-American (Chen, 2010). The Japanese scholar Yabuuchi (2006) directly points to Brown and Levinson's neglect of hierarchy politeness in their dichotomy.

Drawing upon Scollon \& Scollon's (1995) system of solidarity politeness and hierarchy politeness, Chinese state-owned enterprises, previously representative of the Chinese governmental centralized hierarchy, now shift to performing solidarity politeness in interaction on Sina Weibo, despite some extant hierarchy politeness strategies such as ingratiating and broadcasting, as illustrated by the myriad discursive strategies applied in terms of stylistic features and semantic attitudes. This pragmatic turn empirically corroborates an emerging phenomenon of transculturality on social media, which turns to dissolving the ongoing East-West dichotomous divide about face or politeness. And this tendency towards transcultural pragmatics is consistent with the hybridization in a global virtual culture and the neoliberalist movement in China's marketoriented economy.

\section{References}

Ajzen, I. (2005). Attitudes, personality and behavior. Maidenhead, England: Open University Press.

Arnold, M. B. (1960). Emotion and personality: Vol.1. Psychological aspects. New York: Columbia University Press.

Atay, A. (2018). Mediated critical intercultural communication. In A. Atay \& S. Toyosaki (Eds.), Critical intercultural communication pedagogy (pp. 179-194). Lanham, MD: Lexington Books.

Atay, A., \& D'Silva, M. U. (2019). New directions in mediated intercultural communication. In A. Atay \& M. U. D'Silva, Mediated intercultural communication in a digital age (pp.1-6). Abingdon, Oxon: Routledge.

Biber, D. (1988). Variation across speech and writing. England \& New York: Cambridge University Press.

Brown, P., \& Levinson, S. C. (1987). Politeness: Some universals in language use. Cambridge: Cambridge University Press. Cao, S. (2018). Analysis of the neologism “Da call”. Sinogram Culture, 214(20), 89-91.

Chen, R. (2010). Pragmatics East and West: Similar or different? In A. Trosborg (Eds.), Pragmatics across languages and cultures (pp.167-188). Berlin/New York: De Gruyter Mouton. 
Crystal, D. (2006). Language and the internet (2nd ed.). Cambridge, UK; New York: Cambridge University Press.

Dvorak, J. D. (2015). "Prodding with prosody": Persuasion and social influence through the lens of appraisal theory. Biblical and Ancient Greek Linguistics, 4, 85-120.

Dhandhnia, K. A. \& Tripathi, S. (2018). Emotional Branding Through Celebrity Endorsements. In R. Garg, R. Chhikara, T. K. Panda, \& A. Kataria (Eds.), Driving customer appeal through the use of emotional branding (pp. 273-287). Hershey, PA: IGI Global.

Edwards, D. (1994). Script formulations: An analysis of event descriptions in conversation. Journal of Language and Social Psychology, 13 (3), 211-247.

Erickson, R. J. (1995). The importance of authenticity for self and society. Symbolic Interaction, 18(2), 121-144.

Feng, D. (2012). Modeling appraisal in film: a social semiotic approach. PhD thesis, National University of Singapore.

Feng, D. (2016). Promoting moral values through entertainment: A social semiotic analysis of the Spring Festival Gala on China Central Television. Critical Arts, 30 (1), 87-101.

Feng, D. (2017). Metonymy and visual representation: Towards A social semiotic framework of visual metonymy. Visual Communication, 16(4), 441-466.

Feng, D., \& Wignell, P. (2011). Intertextual voices and engagement in TV advertisements. Visual Communication, 10(4), 565-588.

Feng, J., \& Wu, D. D. (2007). Generic intertextuality in advertising discourses and social changes in Mainland China: The case of advertisements in People's Daily in 1980 and 2000. The Chinese Journal of Communication and Society, (2), 161-177.

Feng, J., \& Wu, D. D. (2009). Changing ideologies and advertising discourses in China: A case study of Nanfang Daily. Journal of Asian Pacific Communication, 19(2), 218-238.

Feng, W., \& Wu, D. D. (2017). State-owned or otherwise: Dialogic construction of corporate identities by Chinese banks on Sina Weibo. Intercultural Communication Studies, 25(2), 63-81.

Gajjala, R. (2006). Cyberethnography: Reading South Asian digital diaspora. In K. Landzelius (Eds.), Native on the net: Indigenous and diasporic peoples in the virtual age (pp. 272-291). London, UK: Routledge.

Gobé, M. (2009). Emotional branding: The new paradigm for connecting brands to people. New York: Allworth Press.

Grice, H. P. (1975). Logic and conversation. In P. Cole, \& J.L. Morgan (Eds.), Syntax and Semantics (pp.41-58). New York: Academic Press.

Gu, Y. (1990). Politeness phenomena in modern Chinese. Journal of Pragmatics, 14(2), 237-257.

Guo, M. (n.d.). 2019 BrandZTM Top 100 Most Valuable Chinese Brands. Retrieved May 24, 2021, from https://www.kantar.com/en-cn/inspiration/brands/2019-brandz-top-100-most-valuable-chinese-brands

Halliday, M. A. K. (2014). Halliday's introduction to functional grammar. Milton Park, Abingdon, Oxon: Routledge.

Harter, S. (2002). Authenticity. In C.R. Snyder \& S.J. Lopez (Eds.), Handbook of positive psychology (pp. 382-394). New York: Oxford University Press.

Herskovitz, S., \& Crystal, M. (2010). The essential brand persona: Storytelling and branding. Journal of Business Strategy, $31(3), 21-28$.

Huang, Y. (2008). Capitalism with Chinese Characteristics: Entrepreneurship and the State. Cambridge: Cambridge University Press.

Hyland, K. (1998). Exploring corporate rhetoric: Metadiscourse in the CEO's Letter. Journal of Business Communication, 35(2), 224-244.

Hyland, K. (2005). Metadiscourse: Exploring interaction in writing (Continuum discourse series.). London: Continuum.

Jabreel, M., Moreno, A., \& Huertas, A. (2017). Semantic comparison of the emotional values communicated by destinations and tourists on social media. Journal of Destination Marketing \& Management, 6(3), 170-183.

Jeong, S. (2008). Visual metaphor in advertising: Is the persuasive effect attributable to visual argumentation or metaphorical rhetoric?. Journal of Marketing Communications, 14(1), 59-73.

Jørgensen, P. E. F., \& Isaksson, M. (2010). Credibility in corporate discourse. In A. Trosborg (Eds.), Pragmatics across languages and cultures (pp.513-541). Berlin/New York: De Gruyter Mouton.

Karmark, E. (2008). Corporate branding and corporate reputation. In C.E. Carroll (Eds.), Handbook of Communication and Corporate Reputation (pp.446-458). Chichester, West Sussex; Malden, MA: Wiley-Blackwell.

Keating, E., \& Duranti, A. (2011). Discourse and culture. In Van Dijk, T. A. (Eds.), Discourse studies: A multidisciplinary introduction (pp. 331-356). London: SAGE Publications Ltd.

Kress, G. R., \& van Leeuwen, T. (2006). Reading Images: A Grammar of Visual Design. London, UK: Routledge.

Labov, W. (1972). Language in the inner city: Studies in the Black English vernacular. Philadelphia: University of Pennsylvania Press.

Lee, M.Y.P., \& So, D.W.C. (2007). Corporate-slogans of corporations operating in Greater China. Corporate Communications: An International Journal, 12(1), 58-74.

Li, C., \& Wu, D. D. (2016). An analysis of relational acts in corporate micro-blogs. Chinese Journal of ESP, 7(2): 30-40.

Li, C. \& Wu, D. D.(2018). Facework by global brands across Twitter and Weibo. Discourse, Context \& Media, 26, 32-42.

Liddicoat, A. J. (2011). An introduction to conversational analysis. London \& New York: Continuum. 
Lillqvist, E., \& Louhiala-Salminen, L. (2013). Facing Facebook: Impression management strategies in company-consumer interactions. Journal of Business and Technical Communication, 28(1), 3-30.

Liu, W., \& Liu, W. (2014). Analysis on the word-formation of English netspeak neologism. Journal of Arts \& Humanities, 12(3): 22-30.

Mairinger, M. (2008). Branding 2.0-Using Web 2.0 principles to build an open source brand. Electronic Markets, 18, 117119.

Mao, L. R. (1994). Beyond politeness theory: "Face" revisited and renewed. Journal of Pragmatics, 21(5): 451-486.

Martin, J. R., \& White, P. R. R. (2005). The language of evaluation: Appraisal in English. Houndmills, Basingstoke, Hampshire; New York: Palgrave Macmillan.

Mathew, N., \& Dixit, A. (2018). Emotional branding and social media: Positive and negative emotional appeals. In R. Garg, R. Chhikara, T. K. Panda, \& A. Kataria (Eds.), Driving customer appeal through the use of emotional branding (pp. 289-302). Hershey, PA: IGI Global.

Men, L. R. \& Tsai, W. S. (2012). How companies cultivate relationships with publics on social network sites: Evidence from China and the United States. Public Relations Review, 38, pp.723-730.

Morrison, S. \& Crane, F. G. (2007). Building the service brand by creating and managing an emotional brand experience. Journal of Brand Management, 14(5), 410-421.

Nonini, D. M. (2008). Is China becoming neoliberal? Critique of Anthropology, 28 (2), pp.145-176.

Normann, R., \& Ramirez, R .(1993). From value chain to value constellation: Designing interactive strategy. Harvard Business Review, 71(4), 65-77.

Ong, A. (2007). Neoliberalism as a mobile technology. Transactions of the Institute of British Geographers, 32 (1), pp.3-8.

O'Shaughnessy, J. \& O'Shaughnessy, N. J. (2003). The marketing power of emotion. New York: Oxford University Press.

Pan, Y. \& Kádár, D. Z. (2011). Historical vs. contemporary Chinese linguistic politeness. Journal of Pragmatics, 43(6), 1525-1539.

Chandra, S. P., \& Raghunath, K. M. K. (2018). Emotional branding as a strategy in promoting customer loyalty. In R. Garg, R. Chhikara, T.K. Panda, \& A. Kataria (Eds.), Driving Customer Appeal Through the Use of Emotional Branding (pp. 225-246). Hershey, PA: IGI Global.

Pitt, L. F., Watson, R.T., Berthon, P.,, Wynn, D., \& Zinkhan, G. (2006). The penguin's window: Corporate brands from an open-source perspective. Journal of the Academy of Marketing Science, 34, 115-127.

Pogacar, R., Lowrey, T. M., \& Shrum, L.J. (2017). The influence of marketing language and brand attitudes and choice. In L. Solomon, M. R. Solomon, T.M. Lowrey (Eds.), The Routledge Companion to Consumer Behavior (pp.263-275). London, UK: Routledge.

Reghunadhan, R. (2018). Political economy of digitalization and (state) neoliberalism in China with special reference to 'Made in China 2025'. RSC, 10(3), pp.22-42.

Schegloff, E.A. \& Sacks, H. (1973). Opening up closings. Semiotica, 7, 289-327.

Scollon, R., Scollon, S. W. \& Jones, R. H. (2001). Intercultural communication: A discourse approach (2nd ed.). Malden, Mass.: Blackwell.

Shuter, R. (2012). Intercultural new media studies: The next frontier in intercultural communication. Journal of Intercultural Communication Research, 41(3), 219-237.

Shuter, R., Cheong, P., \& Chen, Y. (2017). The influence of cultural values on U.S. and Danish students' digital behavior: Exploring culture, new media and social context. Journal of International and Intercultural Communication, 9(2), 161-178.

Smith, M. (1995). Engaging characters: fiction, emotion, and the cinema. Oxford: Oxford University Press.

So, A.Y. (2007). Globalization and the transition from neoliberal capitalism to state developmentalism in China. International Review of Modern Sociology, 33(2), 61-76.

Thompson, C. J. , Rindfleisch, A., \& Arsel, Z. (2006). Emotional branding and the strategic value of the doppelgänger brand image. Journal of Marketing, 70(1), 50-64.

Vernuccio, M. (2014). Communicating corporate brands through social media: An exploratory study. International Journal of Business Communication, 51(3), 211-233.

Waters, R. D., Burnett, E., Lamm, A., \& Lucas, J. (2009). Engaging stakeholders through social networking: How nonprofit organizations are using Facebook. Public Relations Review, 35 (2), pp. 102-106.

Weber, I. M. (2018). China and neoliberalism: Moving beyond the China is/is not neoliberal dichotomy. In D. Cahill, M. Konings, M. Cooper, D. Primrose (Eds.), SAGE Handbook of Neoliberalism (pp. 219-233). SAGE Publications.

Weibo Corporation. (2019, August 19). Weibo Reports Second Quarter 2019 Unaudited Financial Results. https://weibocorporation.gcs-web.com/news-releases/news-release-details/weibo-reports-second-quarter-2019unaudited-financial-results.

Weibo Corporation. (n.d.) Business Overview. https://weibocorporation.gcs-web.com/corporate-profile

Wu, D. D. \& Li, C. (2018). Emotional branding on social media: A cross-cultural discourse analysis of global brands on Twitter and Weibo. In A. Curtis \& R. Sussex (Eds.), Intercultural communication in Asia: Education, language and values (pp. 225-240). Cham: Springer International Publishing.

Wu, D. D. \& Li, C. (2019). Cross-cultural studies of new media discourse. Intercultural studies forum, 1 (1), 89-102. 
Wu, D. D. \& Feng, W. (2015). Pragmatist, evangelist, or sensualist? Emotional branding on Sina Weibo. In P. P. K. Ng., \& C. S. B. Ngai (Eds.), Role of language and corporate communication in Greater China (pp.225-239). Heidelberg, New York, Dordrecht, London: Springer.

Wu, D. D \& Chung, M. K. (2006). Involvement strategies in Hong Kong print advertisements, 1950s and 1980s. China Media Research, 2(2):24-37.

$\mathrm{Wu}, \mathrm{F}$. (2010). How neoliberal is China's reform? The origins of change during transition. Eurasian Geography and Economics, 51 (5), 619-631.

Yabuuchi, A. (2006). Hierarchy politeness: What Brown and Levinson refused to see. Intercultural Pragmatics, 3(3):323351.

Zappavigna, M. (2012). The Discourse of Twitter and Social Media. London: Continuum. 